\title{
CONTROL AND MANAGEMENT OF LETTUCE BIG-VEIN DISEASE
}

\author{
J.D. FLETCHER ${ }^{1}$, C. FRANCE ${ }^{2}$ and R.C. BUTLER ${ }^{1}$ \\ ${ }^{1}$ Crop \& Food Research, Private Bag 4704, Christchurch, New Zealand \\ ${ }^{2}$ LeaderBrand Produce, Gisborne, New Zealand \\ Corresponding author: fletcherj@crop.cri.nz.
}

\begin{abstract}
Virus surveys of lettuces over the past two seasons have confirmed that a number of virus diseases still threaten lettuce production. Lettuce big-vein disease (LBVD), caused by Mirafiori lettuce big-vein virus (MLBVV), was found to be the most common. For example, LBVD was present in $30 \%$ of spring crops and $41 \%$ of winter Pukekohe crops, but its incidence within crops varied from $8 \%$ in summer to $50 \%$ in winter. Similarly, $42 \%$ of lettuce crops around Gisborne developed LBVD in spring while $60 \%$ displayed symptoms in winter, with incidences from 10 to 50\%. In Christchurch $10 \%$ of crops were affected in spring and 60\% in winter, with incidences between 1 and $30 \%$. LBVD is transmitted by zoospores of the soil fungus Olpidium brassicae, which is prevalent in cool moist conditions. Control of this vector is an important factor in disease management. Survey results are outlined and experiments using chemicals to control the fungal vector of this virus are described.
\end{abstract}

\section{DIAGNOSTIC PROTOCOLS FOR THE DETECTION OF THREE EXOTIC BACTERIAL PLANT PATHOGENS}

\author{
M. BRAITHWAITE \\ National Plant Pest Reference Laboratory, MAF, PO Box 24, Lincoln, \\ New Zealand \\ Corresponding author: Mark.Braithwaite@maf.govt.nz.
}

Diagnostic protocols have been prepared, tested and implemented at the National Plant Pest Reference Laboratory, Lincoln, for three significant exotic bacterial pathogens, namely, Clavibacter michiganensis ss. sepedonicus (potato ring rot), Xanthomonas axonopodis pv.citri (citrus canker) and Xylella fastidiosa (Pierce's disease of grapes). The protocols include disease symptomology, sample collection, isolation techniques and identification methods. A balance of internationally recognised tests specific to each organism and molecular techniques (predominantly PCR) are used. Reliable, quick and accurate identifications greatly assist the management of disease outbreaks and are critical if eradication measures are to be successful. These testing protocols compliment pest profiles and delimiting survey procedures developed for these organisms. This poster presents the testing procedures for each of these organisms. 